\title{
UJI AKTIVITAS ANTIBAKTERI EKSTRAK KULIT BUAH DELIMA MERAH (Punica granatum L.) TERHADAP PERTUMBUHAN (Vibrio cholera)
}

\author{
Ferdinan M. Yunus, Sonya Titin Nge, Alan Ch. Sabuna \\ Program Studi Pendidikan Biologi, Fakultas Keguruan dan Ilmu Pendidikan, Universitas Kristen Artha Wacana \\ Kupang - NTT \\ Coressponding Author : sonyatitin_nge@yahoo.com
}

\begin{abstract}
ABSTRAK
Kolera adalah penyakit infeksi saluran usus yang bersifat akut dan disebabkan oleh bakteri Vibrio cholerae. Bila bakteri ini mencemari makanan dan terkonsumsi dalam jumlah yang banyak, maka dapat menyebabkan penyakit diare. Upaya mencegah penyakit diare yaitu salah satu alternatif untuk mengatasi resistensi antibiotik yang berpotensi mengobati diare adalah kulit buah delima merah. Tujuan penelitian untuk mengetahui pengaruh ekstrak kulit buah delima merah dan konsentrasi yang efektif ekstrak kulit buah delima merah terhadap pertumbuhan Vibrio cholerae. Uji antibakteri dilakukan dengan metode difusi cakram kertas. Metode yang digunakan dalam penelitian ini adalah metode Eksperimen, yang terdiri dari 5 perlakuan $\mathrm{A} 0=0$ (kontrol), $A 1=25 \mathrm{mg} / \mathrm{ml}, A 2=50 \mathrm{mg} / \mathrm{ml}, A 3=75 \mathrm{mg} / \mathrm{ml}$ dan $A 4=100 \mathrm{mg} / \mathrm{ml}$ dan $3 \mathrm{kali}$ ulangan. Hasil pengamatan dianalisis secara statistik menggunakan analisis variansi (ANOVA) satu jalur dengan taraf signifikansi $5 \%$. Analisis statistik dilakukan dengan menggunakan program SPSS versi 16.0. Hasil penelitian menunjukan bahwa adanya pengaruh ekstrak kulit buah delima merah terhadap pertumbuhan Vibrio cholera dan efektif konsentrasi $100 \mathrm{mg} / \mathrm{ml}$ dan dapat di lihat pada nilai signifikan menunjukan 0,00 dalam hal ini lebih kecil dari pada $0,05(0,00 \leq 0,005)$ yang artinya ada perbedaan antara kontrol dengan perlakuan $A 1, A 2, A 3$ dan A4. Sehingga dibuktikan dengan terbentuknya diameter rata-rata zona bening pada setiap konsentrasi ekstrak kulit buah delima merah secara berturut-turut yaitu: $25 \mathrm{mg} / \mathrm{ml}=6,7 \mathrm{~mm}, 50 \mathrm{mg} / \mathrm{ml}=7,3 \mathrm{~mm}, 75 \mathrm{mg} / \mathrm{ml}=8,0 \mathrm{~mm}$ dan $100 \mathrm{mg} / \mathrm{ml}=11,3 \mathrm{~mm}$.
\end{abstract}

Kata kunci : Aktivitas antibakteri, Punica granatum L, Vibrio cholerae.

\begin{abstract}
Cholera is an infectious disease acute intestinal tract and caused bybacteria Vibrio cholerae. If this bacteria contaminates food and is consumed in large amounts, it can cause diarrhea. Efforts to prevent diarrhea, which is one alternative to overcome antibiotic resistance that has the potential to treat diarrhea, is the skin of red pomegranates. The aim of the study was to determine the effect of red pomegranate skin extract and effective concentration of red pomegranate peel extract on the growth of Vibrio cholerae. Antibacterial test is done by paper disk diffusion method. The method used in this research is the experimental method, which consists of 5 treatments $A O=O$ (control), $A 1=25 \mathrm{mg} / \mathrm{ml}, A 2=50 \mathrm{mg} / \mathrm{ml}, A 3=75 \mathrm{mg} / \mathrm{ml}$ and $A 4=100 \mathrm{mg} /$ $\mathrm{ml}$ and 3 repetitions. Observations were statistically analyzed usinganalysis one-way ANOVA with a significance level of 5\%. Statistical analysis was performed using the SPSS version 16.0 program. The results showed that the effect of red pomegranate peel extract ongrowth Vibrio cholera and effective concentration of $100 \mathrm{mg} / \mathrm{ml}$ and can be seen at a significant value shows 0.00 in this case smaller than $0.05(0.00 \leq 0.005)$ which means there is a difference between the control with the treatment of A1, A2, A3 and A4. So that is evidenced by the formation of the average diameter of the clear zone at each concentration of red pomegranate skin extract, respectively: $25 \mathrm{mg} / \mathrm{ml}=6.7 \mathrm{~mm}, 50 \mathrm{mg} / \mathrm{ml}=7.3 \mathrm{~mm}, 75 \mathrm{mg} / \mathrm{ml}=8,0 \mathrm{~mm}$ and $100 \mathrm{mg} / \mathrm{ml}=11.3 \mathrm{~mm}$.
\end{abstract}

Keywords: Antibacterial activity, Punica granatum L, Vibrio cholerae. 


\section{PENDAHULUAN}

Kolera adalah penyakit infeksi saluran usus yang bersifat akut dan disebabkan oleh bakteri Vibrio cholerae. Kolera dapat menular sebagai penyakit yang bersifat epidemik. Meskipun sudah banyak penelitian berskala besar dilakukan, namun penyakit ini tetap menjadi suatu tantangan bagi dunia kesehatan. Menurut pendataan Dinas Kesehatan Provinsi Nusa Tenggara Timur, jumlah penderita penyakit diare di Kota Kupang dari tahun 2014 sampai 2016 menunjukan ada peningkatan kasus penderita penyakit diare, dimana jumlah penyakit pada tahun 2014 berjumlah 8.134 jiwa, pada tahun 2015 berjumlah 8.365 jiwa dan pada tahun 2016 yaitu 8.609 jiwa. Peningkatan penyakit diare seharusnya diimbangi dengan pelayanan yang semakin baik dari waktu ke waktu. Kondisi lingkungan yang kurang dijaga kebersihannya sangat berpengaruh secara signifikan pada tingkat keseahatan masyarakat Kota Kupang yang mengalami masalah infeksi saluran pencernaan akibat bakteri patogen.

Penyakit kolera ditandai oleh terjadinya diare yang disertai oleh muntah-muntah yang akut dan hebat sebagai akibat dari enterotoksin (zat racun) yang dihasilkan bakteri tersebut. Bentuk gejala klinis yang khas pada penderita adalah dehidrasi, berlanjut dengan rejatan hipovolemik dan asidosis metabolik yang terjadi dalam waktu singkat akibat diare sekretorik. Vibrio cholerae merupakan bakteri gram-negatif, bakteri ini dapat tumbuh pada $\mathrm{pH}$ yang sangat tinggi $(8,5-9,5)$ dengan suhu untuk pertumbuhan yang berkisar antara 18 sampai $37^{\circ} \mathrm{C}$. Vibrio cholerae adalah salah satu mikroba penyebab penyakit yang sering ditemukan pada makanan (Siagan, 2002). Bila bakteri ini mencemari makanan dan terkonsumsi dalam jumlah yang banyak, maka dapat menyebabkan penyakit diare.

Upaya mencegah penyakit diare, dilakukan dengan pemberian antibiotik seperti ampicilin, kanamisin. Namun tidak semua obat kimia tersebut dapat dijangkau oleh masyarakat khususnya masyarakat pedesaan, karena faktor ekonomi, sosiologi, maupun efek samping yang dapat membunuh normal flora (mikroba yang secara alamiah menghuni tubuh manusia). Oleh karena itu, selain pengobatan obat modern, salah satu alternatif untuk mengatasi masalah resistensi antibiotik yaitu penggunaan tanaman obat tradisional dianggap relatif lebih aman dibandingkan dengan obat sintesis, hal ini dikarenakan tanaman atau bahan alam lebih mudah diperoleh, lebih murah dan juga tidak memiliki efek samping serta tingkat toksisitasnya jauh lebih rendah.

Kekayaan jenis tanaman herbal di Indonesia sangat melimpah, termasuk di dalamnya adalah tanaman sumber daya alam yang berpotensi untuk mengobati diare. Salah satu tanaman yang berpotensi untuk mengobati diare adalah buah delima merah. Buah delima merah mengandung senyawa flavonoid dan tannin. Berdasarkan penelitian fitokimia yang dilakukan oleh Purwani (2015) terhadap kulit buah delima merah dan hasilnya menunjukan bahwa kulit buah delima merah mengandung senyawa flavonoid dan tanin yang memiliki aktivitas antibakteri, dan ada juga yang mengatakan bahwa mengandung senyawa metabolit sekunder berupa flavonoid, saponin dan tannin, berdasarkan penelitian uji skrining fitokimia oleh Muthmainnah (2017).

Dari penelitian terdahulu yang dilakukan oleh Sundari dan Nuratmi, (1999) efek antibakteri ekstrak alkohol $70 \%$ kulit buah delima (Punica granatum L.) terhadap bakteri Vibrio dengan menggunakan konsentrasi 137,6 mg/ml bahwa, bahan ekstrak menunjukan hasil positif, sehingga peneliti melakukan penelitian lanjutan dengan perbandingan menggunakan pelarut etanol $96 \%$ dengan variasi konsentrasi mulai dari 25, 50, 75 dan 100 dalam satuan $\mathrm{mg} / \mathrm{ml}$, dimana lebih kecil dari konsentarsi yang dilakukan oleh peneliti sebelumnya, dari penelitian ini dengan menggunakan pelarut $96 \%$ zat aktif sehingga mendapatkan senyawa yang mempunyai toksisitas kuat untuk menghambat pertumbuhan bakteri dari ekstrak kulit buah delima merah.

Dari uraian di atas maka penulis telah melakukan penelitian dengan judul : "Uji Aktivitas Antibakteri Ekstrak Kulit Buah Delima Merah (Punica granatum L.) Terhadap Pertumbuhan Vibrio cholerae". Tujuan dalam penelitian ini adalah Untuk mengetahui pengaruh ekstrak dan konsentrasi efektif ekstrak kulit buah delima merah (Punica granatum L.) terhadap pertumbuhan bakteri Vibrio cholerae.

\section{METODE PENELITIAN}

\section{Waktu dan Tempat Penelitian}

Penelitian ini telah dilaksanakan pada bulan Maret sampai Mei 2018, bertempat di Laboratorium Biologi Universitas Kristen Artha Wacana Kupang. 


\section{Alat dan Bahan}

Peralatan yang digunakan dalam penelitian ini adalah timbangan analitik, oven, pisau, blender, rotary evaporator, erlenmeyer $250 \mathrm{ml}$, gelas ukur, beaker gelas, tabung reaksi, rak tabung reaksi, mikropipet, autoclave, batang L, cawan petri, jarum ose, hot plate with magnetic stirer, pinset, inkubator, vortex, corong kaca, penggaris berskala, log book dan kamera.

Bahan yang digunakan dalam penelitian ini adalah air, alkohol, aquadest steril, Nutrient Agar (NA), kapas steril, alumnium foil, etanol 96\%, biakan bakteri Vibrio cholerae, ekstrak kulit buah delima merah (Punica granatum L.), kertas cakram, kertas whatman dan kertas label.

\section{Metode Penelitian}

Metode yang digunakan dalam penelitian ini adalah metode Eksperimen, yang terdiri dari 5 perlakuan dan 3 ulangan. Dengan perlakuan sebagai berikut :

A0 : Tanpa pemberian ekstrak kulit buah delima merah (Punica granatum L.) $0 \mathrm{mg} / \mathrm{ml}$ (kontrol)

A1 : Pemberian ekstrak kulit buah delima merah (Punica granatum L.) $25 \mathrm{mg} / \mathrm{ml}$

A2 : Pemberian ekstrak kulit buah delima merah (Punica granatum L.) $50 \mathrm{mg} / \mathrm{ml}$

A3 : Pemberian ekstrak kulit buah delima merah (Punica granatum L.) $75 \mathrm{mg} / \mathrm{ml}$

A4 : Pemberian ekstrak kulit buah delima merah (Punica granatum L.) $100 \mathrm{mg} / \mathrm{ml}$

\section{Prosedur Penelitian}

\section{Tahap persiapan Alat dan Bahan}

Alat yang digunakan dalam penelitian ini disiapkan dan dicuci bersih dengan air mengalir dan dikeringkan kemudian disterilisasi dengan menggunakan oven dengan suhu $180^{\circ} \mathrm{C}$ selama \pm 1 jam. Sedangkan bahan yang digunakan adalah kulit buah delima merah (Punica granatum L.) yang diperoleh dari lingkungan sekitar Manulai I kecamatan Kupang Barat, diambil sebanyak 400 gram, dan bakteri Vibrio cholerae diperoleh dari BPOM Kupang (Badan Pengawasan Obat dan Makanan).

\section{Tahap pembuatan ekstrak kulit buah delima merah (Punica granatum $L$.)}

Kulit buah delima merah (Punica granatum L.) segar dicuci dan dikeringkan. Setelah kering dibuat serbuk halus dengan menggunakan blender serbuk kulit buah delima merah (Punica granatum L.) dimaserasi dengan pelarut etanol $96 \%$ sebanyak $1000 \mathrm{ml}$ dan diamkan selama \pm 24 jam. Serbuk kulit buah delima merah (Punica granatum L.) yang sudah dimaserasi disaring dengan menggunakan kertas whatman sehingga memperoleh filtrat, selanjutnya filtrat tersebut dimasukan ke dalam rotary evaporator dengan suhu $40^{\circ} \mathrm{C}$, selama \pm 2 jam sehingga memperoleh ekstrak pekat sebanyak 30,8 gram. Kemudian ekstrak diencerkan dengan aquadest sehingga memperoleh konsentrasi $0 \mathrm{mg} / \mathrm{ml}, 25$ $\mathrm{mg} / \mathrm{ml}, 50 \mathrm{mg} / \mathrm{ml}, 75 \mathrm{mg} / \mathrm{ml}$, dan $100 \mathrm{mg} / \mathrm{ml}$.

\section{Tahap pembuatan medium Nutrient Agar (NA)}

Timbang sebanyak 20 gram Nutrient Agar (NA) dan dimasukan kedalam Erlenmeyer, kemudian ditambahkan aquadest dengan volume 1 liter. Selanjutnya dipanaskan di atas hot plate sehingga larutan homogen. Untuk pembuatan agar miring, masukan NA kedalam 5 tabung reaksi dengan masing-masing sebanyak $5 \mathrm{ml}$ kemudian tabung di tutup dengan kapas dan disterilisasi dengan autoclave $\left(121^{\circ} \mathrm{C}\right.$, selama 15 menit). Setelah disterilisasi tabung segera di miringkan pada rak tabung sampai dingin. Untuk pembuatan Medium NA setelah dilakukan sterilisasi, medium larutan agar dalam erlenmeyer kemudian secara aseptik dituang ke dalam cawan petri dengan masing-masing petridish \pm $15 \mathrm{ml}$ dan diamkan pada suhu ruang.

\section{Tahap Uji Antibakteri}

Menginokulasi isolat bakteri Vibrio cholerae pada 4 agar miring dan di inkubasi pada suhu $37^{\circ} \mathrm{C}$ selama 48 jam. Setelah mendapat biakan murni bakteri Vibrio cholerae, ambil bakteri tersebut dari agar miring ke dalam tabung reaksi yang berisikan aquadest dengan menggunakan jarum ose kemudian di vortex setelah itu di pindahkan ke 5 petridish steril (agar plate) dengan mengunakan mikropipet dan metode spread plate. Kemudian encerkan ekstrak kulit buah delima merah (Punica granatum) dengan 
konsentrasi $0 \mathrm{mg} / \mathrm{ml}, 25 \mathrm{mg} / \mathrm{ml}, 50 \mathrm{mg} / \mathrm{ml}, 75 \mathrm{mg} / \mathrm{ml}$, dan $100 \mathrm{mg} / \mathrm{ml}$. yang mana setiap perlakuan terdapat 3 ulangan, kemudian direndam kertas cakram steril $(3 \mathrm{~mm})$, selama 15 menit. Selanjutnya, meletakkan kertas cakram tersebut dengan mengunakan pinset diatas inokulum bakteri dalam petridish yang mana totalnya terdapat 5 perlakuan termasuk kontrol dan 3 ulangan. Kemudian menginkubasikan pada suhu $37^{\circ} \mathrm{C}$ selama 24 jam. Kemudian mengamati dan mengukur lebar diameter zona hambat ekstrak kulit buah delima merah (Punica granatum L.) terhadap pertumbuhan bakteri Vibrio cholera yang ditandai dengan adanya zona bening.

\section{Parameter yang diukur}

Adapun parameter yang akan diamati dalam penelitian ini yaitu diameter zona hambat ekstrak kulit buah delima merah (Punica granatum L.) terhadap pertumbuhan bakteri Vibrio cholerae berupa daerah bening pada permukaan medium.

\section{Teknik Analisis Data}

Analisis data yang digunakan dalam penelitian ini adalah analisis deskriptif kuantitatif dengan didapatkan data berupa diameter zona bening yang terbentuk pada cawan petri berisi NA yang terinokulasi bakteri Vibrio cholerae yang telah diberi ekstrak kulit buah delima merah (Punica granatum L.). Aktivitas antibakteri dapat digolongkan berdasarkan besarnya zona hambat yang terbentuk akibat pengaruh ekstrak kulit buah delima merah dengan menggunakan pelarut etanol $96 \%$. Susanto. $d k k$, (2012) menyebutkan kategori zona hambat dapat diketahui pada Tabel 1.

Tabel 1. Kategori Diameter zona Hambat

\begin{tabular}{cc}
\hline Diameter & Kekuatan Daya Hambat \\
\hline$\leq 5 \mathrm{~mm}$ & Lemah \\
\hline $6-10 \mathrm{~mm}$ & Sedang \\
\hline $11-20 \mathrm{~mm}$ & Kuat \\
\hline$\geq 21 \mathrm{~mm}$ & Sangat kuat \\
\hline
\end{tabular}

Diameter zona hambat diukur dengan menggunakan rumus (Torar dkk, 2015) :

Keterangan

$$
\text { Diameter zona hambat }=\frac{(\mathrm{DV}-\mathrm{DC})+(\mathrm{DH}-\mathrm{DC})}{2}
$$

DV: Diameter vertikal DH: Diameter horisontal DC: Diameter cakram

Data hasil pengamatan dianalisis secara statistik menggunakan analisis variansi ANOVA satu jalur dengan taraf signifikansi $5 \%$. Analisis statistic dilakukan dengan menggunakan program SPSS versi 16.0. ANOVA merupakan suatu uji yang dilakukan menurut distribusi F. ANOVA dimaksudkan untuk menguji pengaruh faktor dari setiap perlakuan terhadap data hasil percobaan (Hanafiah, 2012).

\section{HASIL DAN PEMBAHASAN}

Hasil uji aktivitas antibakteri ekstrak kulit buah delima terhadap pertumbuhan bakteri Vibrio cholera dimulai dari tanpa pemberian ekstrak sebagai kontrol, dan variasi konsentrasi yang digunakan $25 \mathrm{mg} / \mathrm{ml}, 50 \mathrm{mg} / \mathrm{ml}, 75 \mathrm{mg} / \mathrm{ml}$ dan $100 \mathrm{mg} / \mathrm{ml}$. Berdasarkan data rekapitulasi pada tabel 2, pada konsentrasi $0 \mathrm{mg} / \mathrm{ml}$ (kontrol) menunjukkan tidak adanya zona bening yang terbentuk di sekitar kertas cakram. Hal ini disebabkan karena aquadest steril yang digunakan tidak mengandung senyawa antibakteri yang dapat menghambat pertumbuhan sel bakteri Vibrio cholera.

Tabel 2. Hasil Pengukuran zona bening bakteri Vibrio cholerae.

\begin{tabular}{ccccccc}
\hline No & $\begin{array}{c}\text { Konsentrasi ekstrak } \\
\text { kulit buah delima } \\
(\mathrm{mg} / \mathrm{ml})\end{array}$ & \multicolumn{2}{c}{$\begin{array}{c}\text { Diameter zona } \\
\text { bening }(\mathrm{mm})\end{array}$} & $\begin{array}{c}\text { Jumlah } \\
(\mathrm{mm})\end{array}$ & $\begin{array}{c}\text { Rata-rata } \\
(\mathrm{mm})\end{array}$ \\
\cline { 3 - 6 } & & $\mathrm{U} 1$ & $\mathrm{U} 2$ & $\mathrm{U} 3$ & & \\
\hline 1 & 0 & 0 & 0 & 0 & 0 & 0 \\
\hline 2 & 25 & 7 & 6 & 7 & 20 & 6,7 \\
\hline 3 & 50 & 7 & 7 & 8 & 22 & 7,3 \\
\hline
\end{tabular}




\begin{tabular}{ccccccc}
\hline 4 & 75 & 8 & 7 & 9 & 24 & 8,0 \\
\hline 5 & 100 & 11 & 11 & 12 & 34 & 11,3 \\
\hline
\end{tabular}

(Sumber : Data Olahan Penulis, 2018)

Pada penambahan ekstrak kulit buah delima dengan konsentrasi $25 \mathrm{mg} / \mathrm{ml}$ memiliki kemampuan untuk menghambat pertumbuhan bakteri Vibrio cholerae dengan rata-rata diameter zona bening $6,7 \mathrm{~mm}$ sehingga dinyatakan memiliki aktivitas penghambatan sedang. Suatu senyawa digolongkan memiliki aktivitas penghambatan sedang jika pada hasil pengujian menunjukan pembentukan zona bening berkisar pada 6 sampai $10 \mathrm{~mm}$ (Susanto $d k k, 2012$ ).

Hasil pengaruh ekstrak kulit buah delima terhadap pertumbuhan bakteri Vibrio cholerae dengan penambahan ekstrak pada konsentrasi $75 \mathrm{mg} / \mathrm{ml}$ menunjukkan adanya zona bening lebih besar dibanding konsentrasi $25 \mathrm{mg} / \mathrm{ml}$ dan $50 \mathrm{mg} / \mathrm{ml}$. Aktivitas penghambatan ekstrak kulit buah delima pada konsentrasi $75 \mathrm{mg} / \mathrm{ml}$ dikategorikan memiliki aktivitas penghambatan sedang, karena menghasilkan zona bening rata-rata pada kisaran 8,0 atau $\leq 10 \mathrm{~mm}$. Selanjutnya pada penambahan ekstrak kulit buah delima dengan konsentrasi $100 \mathrm{mg} / \mathrm{ml}$ memiliki kemampuan untuk menghambat pertumbuhan bakteri Vibrio cholerae dengan rata-rata diameter zona bening yaitu 11,3 mm, sehingga dinyatakan memiliki aktivitas penghambatan kuat atau $\geq 10 \mathrm{~mm}$. Karena pada hasil pengujian pengaruh ekstrak kulit buah delima terhadap pertumbuhan bakteri Vibrio cholera menunjukan pembentukan zona bening berkisar pada $11 \mathrm{~mm}$ sampai $20 \mathrm{~mm}$ (Susanto dkk., 2012).

Berdasarkan Hasil analisis ANOVA satu jalur (SPSS 16.0), yang di lanjut dengan LSD nilai signifikan menunjukan 0,00 dalam hal ini nilai signifikan lebih kecil dari pada $0,05(0,00<0,05)$ yang artinya ada perbedaan antara perlakuan dengan kontrol, perlakuan A1 dan perlakuan A2 menunjukan nilai signifikan 0,226. Dalam hal ini 0,226 lebih besar dari pada $0,05(0,226>0,05)$ yang artinya tidak ada perbedaan antara perlakuan $\mathrm{A} 1$ dan perlakuan $\mathrm{A} 2$, perlakuan $\mathrm{A} 1$ dan perlakuan $\mathrm{A} 3$ menunjukan nilai signifikan 0,27 . Dalam hal ini 0,27 lebih besar dari pada $0,05(0,27>0,05)$ yang artinya tidak ada perbedaan antara perlakuan A1 dan perlakuan A3, perlakuan A1 dan perlakuan A4 menunjukan nilai signifikan 0.00 . Dalam hal ini 0.00 lebih kecil dari pada $0,05(0.00<0,05)$ yang artinya ada perbedaan antara perlakuan $\mathrm{A} 1$ dan perlakuan $\mathrm{A} 4$, perlakuan $\mathrm{A} 2$ dan perlakuan $\mathrm{A} 1$ menunjukan nilai signifikan 0,226 . Dalam hal ini 0,226 lebih besar dari pada $0,05(0,226>0,05)$ yang artinya tidak ada perbedaan antara perlakuan A2 dan perlakuan A1, perlakuan A2 dan perlakuan A3 menunjukan nilai signifikan 0,226 . Dalam hal ini 0,226 lebih besar dari pada $0,05(0,226>0,05)$ yang artinya tidak ada perbedaan antara perlakuan A2 dan perlakuan A3, perlakuan A2 dan perlakuan A4 menunjukan nilai signifikan 0.00 . Dalam hal ini 0.00 lebih kecil dari pada $0,05(0.00<0,05)$ yang artinya ada perbedaan antara perlakuan A2 dan perlakuan A4, selanjutnya perlakuan A3 dan perlakuan A1 menunjukan nilai signifikan 0,027 . Dalam hal ini 0,027 lebih besar dari pada $0,05(0,027>0,05)$ yang artinya tidak ada perbedaan antara perlakuan A3 dan perlakuan A1, perlakuan A3 dan perlakuan A2 menunjukan nilai signifikan 0,226. Dalam hal ini 0,226 lebih besar dari pada $0,05(0,226>0,05)$ yang artinya tidak ada perbedaan antara perlakuan A3 dan perlakuan A2, perlakuan A3 dan perlakuan A4 menunjukan nilai signifikan 0.00. perlakuan $A 3$ dan perlakuan A4 menunjukan nilai signifikan 0.00 . Dalam hal ini 0.00 lebih kecil dari pada $0,05 \quad(0.00<0,05)$ yang artinya ada perbedaan antara perlakuan A3 dan perlakuan A4, Dalam hal ini 0.00 lebih kecil dari pada $0,05(0.00<0,05)$ yang artinya ada perbedaan antara perlakuan $A 3$ dan perlakuan $A 4$, sedangkan pada perlakuan $A 4$ perlakuan $A 1, A 2$, dan perlakuan A3 menunjukan nilai signifikan 0.00. Dalam hal ini 0.00 lebih kecil dari pada 0,05 $(0.00<0,05)$ yang artinya ada perbedaan antara perlakuan A1, A2, A3 dan perlakuan A4.

Berdasarkan data rekapitulasi pada Tabel 2, dari setiap variasi konsentrasi maka dapat dilihat diameter zona bening pada gambar 1 .
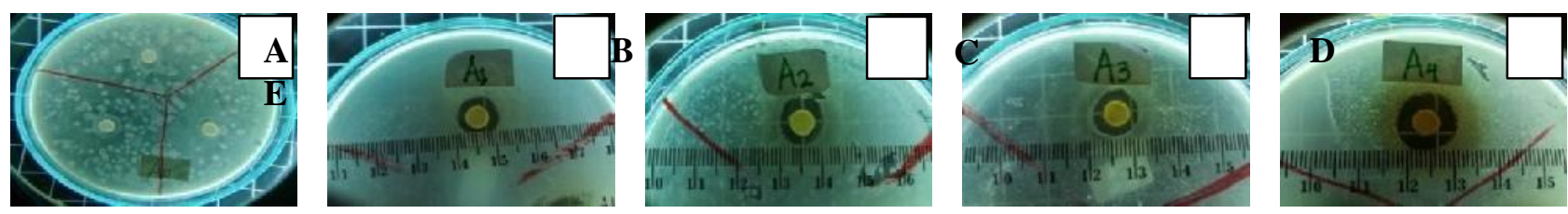

Gambar 1. Diameter zona bening pada setiap konsentrasi ; a). Kontrol (0mg/ml); b). Konsentrasi $(25 \mathrm{mg} / \mathrm{ml})$; c).Konsentrasi (50mg/ml); d). Konsentrasi $(75 \mathrm{mg} / \mathrm{ml}) ; \mathrm{e})$. Konsentrasi $(100 \mathrm{mg} / \mathrm{ml})$ dan hasil gambar ulangan 1 dari setiap konsentrasi. 
Berdasarkan gambar 1 dan hasil rekapitulasi data pada tabel 2, pengaruh ekstrak kulit buah delima merah dapat menghambat pertumbuhan bakteri Vibrio cholerae dan terlihat bahwa semakin tinggi konsentrasi ekstrak maka semakin besar zona bening yang di terbentuk pada sekitar kertas cakram. Hal ini pula disebabkan kulit buah delima merah mempunyai kandungan fitokimia (Purwani, 2015). Sama hal dengan penelitian uji skrining fitokimia oleh Muthmainnah (2017) yang mengatakan bahwa mengandung senyawa metabolit sekunder berupa tannin, saponin dan flavonoid yang menunjukkan bahwa kulit buah delima memiliki aktivitas antibakteri.

Pengaruh ekstrak kulit buah delima merah telah terbukti memiliki potensi antibakteri dalam spektrum yang luas, yaitu dapat menghambat pertumbuhan bakteri gram negatif, karena bakteri Vibrio cholerae termasuk gram negatif dinding selnya tersusun atas peptidoglikan sedang dan komponen khusus berupa lipoprotein, selaput luar dan lipopolisakarida. Dengan mekanisme kerja senyawa tanin yang terkandung dalam kulit buah delima merah diperkirakan mempengaruhi hambatan terhadap pertumbuhan bakteri Vibrio cholerae. Senyawa tanin juga merusak terbentuknya jembatan silang komponen penyusun peptidoglikan pada sel bakteri, sehingga lapisan dinding sel tidak terbentuk secara utuh dan menyebabkan kematian sel tersebut dan mekanisme kerja antibakteri senyawa tanin dalam konsentrasi rendah mampu menghambat pertumbuhan bakteri, sedangkan pada konsentrasi tinggi senyawa tanin mampu bekerja sebagai antibakteri dengan cara mengkoagulasi atau menggumpalkan enzim sehingga terbentuk ikatan yang stabil dengan protein dan mengeliminasi toksin (Lusi, 2016).

Mekanisme kerja antibakteri senyawa saponin yaitu zat aktif yang dapat meningkatkan permeabilitas membran sehingga terjadi hemolisis sel. Apabila saponin berinteraksi dengan bakteri, maka bakteri tersebut akan mengalami lisis atau pecah. Senyawa saponin juga dapat bekerja sebagai antibakteri yang merusak membran sitoplasma dan membunuh sel. Sedangkan senyawa flavonoid diduga mekanisme kerjanya mendenaturasi protein sel bakteri dan merusak membran sel tanpa dapat diperbaiki lagi dan menyebabkan terjadinya kerusakan permeabilitas dinding sel bakteri, mikrosom, dan lisosom sebagai hasil interaksi antara flavonoid dengan DNA bakteri.

Antibakteri yang terdapat pada ekstrak kulit buah delima merah yaitu menghambat atau merusak pembentukan dinding sel bakteri Vibrio cholerae dengan mencegah bergabungnya asam $\mathrm{N}$ asetilmuramat ke dalam struktur peptidoglikan. Penghambatan biosintetik peptidoglikan menyebabkan dinding sel bakteri Vibrio cholerae lemah dan dapat pecah karena tidak dapat menahan tekanan dari sitoplasma. Sehingga mekanisme kerja dari ekstrak kulit buah delima merah memiliki daya sebagai zat antibakteri yang besar dan bersifat bakteriostatis atau kemampuan menghambat pertumbuhan dan reproduksi bakteri (Lusi, 2016).

Mekanisme kerja antibakteri dari flavonoid yaitu fenol yang cenderung mengikat enzim, sehingga mengganggu proses metabolisme sel bakteri. Antibakteri terikat pada reseptor sel yaitu enzim transpeptidase, kemudian terjadi reaksi transpeptidase sehingga sintesis peptidoglikan terhambat dan mekanisme diakhiri dengan penghentian aktivitas penghambat enzim autolisis pada dinding sel (Lusi, 2016).

Kulit buah delima merah memiliki daya hambat yang kuat terhadap pertumbuhan bakteri Vibrio cholerae, terbukti dengan rata-rata diameter zona bening yang terbentuk pada sekeliling kertas cakram mencapai $11,3 \mathrm{~mm}$ pada konsentrasi $100 \mathrm{mg} / \mathrm{ml}$. Hasil penelitian pengaruh ekstrak kulit buah delima merah terhadap pertumbuhan bakteri Vibrio cholera mempunyai perbedaan dengan penelitian oleh Sundari dan Nuratmi (1999) uji efek antibakteri ekstrak kulit buah delima terhadap bakteri penyebab diare dan uji toksisitas akut. Hal ini dibuktikan dengan rata-rata diameter zona bening yang terbentuk dari setiap konsentrasi ekstrak kulit buah delima, dimana dalam penelitian ini diameter zona bening yang lebih besar dan efektif pada konsentrasi $100 \mathrm{mg} / \mathrm{ml}$ yaitu $11,3 \mathrm{~mm}$. Hal ini menunjukkan bahwa dengan konsentrasi $100 \mathrm{mg} / \mathrm{ml}$ ekstrak kulit buah delima memiliki daya hambat yang kuat terhadap pertumbuhan bakteri Vibrio cholera.

\section{Simpulan}

\section{PENUTUP}

Berdasarkan hasil penelitian dapat disimpulkan bahwa ekstrak kulit buah delima merah pada konsentrasi $25 \mathrm{mg} / \mathrm{ml}$ hingga $75 \mathrm{mg} / \mathrm{ml}$ menunjukkan aktivitas antibakteri kategori sedang, sedangkan $100 \mathrm{mg} / \mathrm{ml}$ menunjukkan aktivitas antibakteri kategori kuat terhadap pertumbuhan bakteri Vibrio 
cholerae, dan konsentrasi ekstrak kulit buah delima merah yang efektif terhadap pertumbuhan bakteri Vibrio cholerae adalah $100 \mathrm{mg} / \mathrm{ml}$. Sehingga semakin tinggi konsentrasi ekstrak kulit buah delima merah maka semakin besar diameter zona hambat pada pertumbuhan bakteri Vibrio cholerae.

\section{Saran}

Berdasarkan kesimpulan di atas maka disarankan ekstrak kulit buah delima merah untuk dapat digunakan sebagai zat antibakteri dan disarankan untuk melakukan penelitian lanjutan terhadap jenis bakteri lain misalnya, Salmonella sp, Bacillus cereus dan Escherichia coli.

\section{DAFTAR PUSTAKA}

Dinas kesehatan. 2017. Data penderita penyakit diare. Kota Kupang. Provinsi NTT.

Hanafiah. 2012. Kemas Ali Rancangan Percobaan (Teori Dan Aplikasi). Edisi ketiga. Jakarta : PT Rajagranfino Persada.

Lusi. 2016. Uji Aktivitas Antibakteri Ekstrak Daun Kelor (Moringa oleifera L.) Terhadap Bakteri Escherichia coli dan Staphylococcus aureus. Jurnal IImiah Farmasi -UNSRAT Vol. 5 No. 2 MEI 2016 ISSN 2302 -2493.

Muthmainnah B. 2017. Uji Skrining Fitokimia Senyawa Metabolit Sekunder Dari Ekstrak Etanol Buah Delima (Punica granatum L.) Dengan Metode Uji Warna. Media Farmasi Vol. XIII. No. 2. November 2017

Purwani. 2015. Efek Ektrak Air Kulit Buah Delima (Punica granatum L.) Terhadap Salmonella Typhimurium Secara In Vivo. Jurnal pustaka kesehatan. vol 3 (no.2).

Siagan. 2002. Mikroba Patogen Pada Makanan dan Sumber Pencemarannya. Fakultas Kesehatan Masyarakat. Universitas Sumatera Utara.

Sundari dan Nuratmi. 1999. Efek Antibakteri Ekstrak Kulit Buah Delima (Punica granatum L.) Terhadap Bakteri Penyebab Diare Secara In Vitro Dan Uji Toksisitas Akut. Jurnal Media Litbangkes Edisi Khusus "Obat Asli Indonesia" Vol VIII No 3 \& 4.

Susanto, Sudrajat dan Ruga. 2012. Studi Kandungan Bahan Aktif Tumbuhan Meranti Merah (Shrea leprosula Miq) sebagai sumber senyawa antibakteri. Mulawarman scientifie 11(2):181-190

Torar S. S. Toy, Benedictus S. Lampus \& Bernat S. P. Hutagalung. 2015. Uji Daya Hambat Ekstrak Rumput Laut Gracilaria sp Terhadap Pertumbuhan Bakteri Staphylococcus aureus. Universitas Sam Ratulangi Manado. Jurnal e-GiGi (eG). Volume 3, Nomor 1, Januari-Juni 2015. 
Indigenous Biologi

Jurnal pendidikan dan Sains Biologi

Volume 1(3) 2018 (10-16) 